\title{
History and New Developments on the 90th Anniversary of Cytologia: On the Occasion of the Publication of "Dawn of Modern Wheat Genetics"
}

\author{
Shigeyuki Kawano*† \\ Functional Biotechnology PJ, Future Center Initiative, The University of Tokyo, \\ Wakashiba, Kashiwa, Chiba 277-0871, Japan \\ Received June 16, 2019; accepted August 9, 2019
}

\begin{abstract}
Summary This year marks the 90th anniversary of Cytologia. Modern wheat genetics began 16 years prior to the first issue of Cytologia in 1929. Flaksberger's wheat stocks, which were sent to Minami in October 1913, were used by Sakamura to determine the number of chromosomes in wheat. Flaksberger's death in prison in September 1942 was a tragedy for the research community. The Russian and Soviet contribution to modern wheat genetics is immeasurable, but its decline during and after the era of Lysenko was pitiful. This is made clear by the number of publications from each country since the first issue of Cytologia. The publication of Cytologia continued during World War II; after the war, the contribution of India, which became independent at that time, was considerable. Recently, India's contribution has been relativized, and contributions from other Asian countries including Thailand and Japan, the Middle East and South America have increased, and Cytologia has been supported by increasingly diverse countries.
\end{abstract}

Key words 90th Anniversary of Cytologia, Flaksberger's wheat stocks, Wheat genetics, Indomalayan region, Ichthyology, Cereal cytogenetics, Karyotype.

The review entitled "Dawn of Modern Wheat Genetics: The Story of the Wheat Stocks That Contributed to the Early Stage of Wheat Cytogenetics" by Koichiro Tsunewaki was published in Cytologia last year (Tsunewaki 2018). Tsunewaki, a Professor Emeritus at Kyoto University, expanded Kihara's alien cytoplasm to plasmon analysis of the Triticum-Aegilops complex. This story began in October 1913, when Konstantin Flaksberger, Bureau of Applied Botany, Russia, wrote to Yuzo Hoshino, Hokkaido University, Japan, requesting seeds of Japanese cereals. This was 16 years before the first issue of Cytologia, which included an introductory paper titled "Conjugation of homologous chromosomes in the genus hybrids Triticum $\times$ Aegilops and species hybrids of Aegilops" by Hitoshi Kihara (Kihara 1929). This year marks the 90th anniversary of Cytologia and in this review I focus on its birth and subsequent development based on the above-mentioned review article by Tsunewaki.

\footnotetext{
*Corresponding author, e-mail: kawano@edu.k.u-tokyo.ac.jp

${ }^{\dagger}$ Former editor-in-chief and current editor of Cytologia, and President of the Japan Mendel Society

DOI: $10.1508 /$ cytologia.84.193
}

Wheat stocks that contributed to the early stage of wheat cytogenetics

Four wheat researchers played major roles in Tsunewaki's story: in chronological order these are Konstantin Flaksberger, Takajiro Minami, Tetsu Sakamura, and Hitoshi Kihara.

The wheat stocks sent from Flaksberger to Minami, who initially propagated them at Hokkaido University, left St. Petersburg, Russia, sometime in October 1915, then passed along the $9300 \mathrm{~km}$ of the Trans-Siberian Railway during World War I, and reached Sapporo, Japan, sometime before May 19, 1916. Flaksberger's wheat stocks were sent to Minami, who initially propagated them at Hokkaido University and then provided them to Sakamura, who observed chromosome numbers at the root-tip and pollen mother cell (PMC), and produced crosses in four combinations between $4 x$ and $6 x$ species in the summer of 1917 . These postulated events fit the hypothesis that the wheat stocks sent by Flaksberger to Minami were used by Sakamura to determine the number of chromosomes of wheat.

Tetsu Sakamura had been a graduate student in the Faculty of Agriculture, Hokkaido University, since 1913, carrying out chromosome studies of leguminous species, but he switched to wheat in 1916 and asked Minami to provide wheat seeds. He determined the correct number 


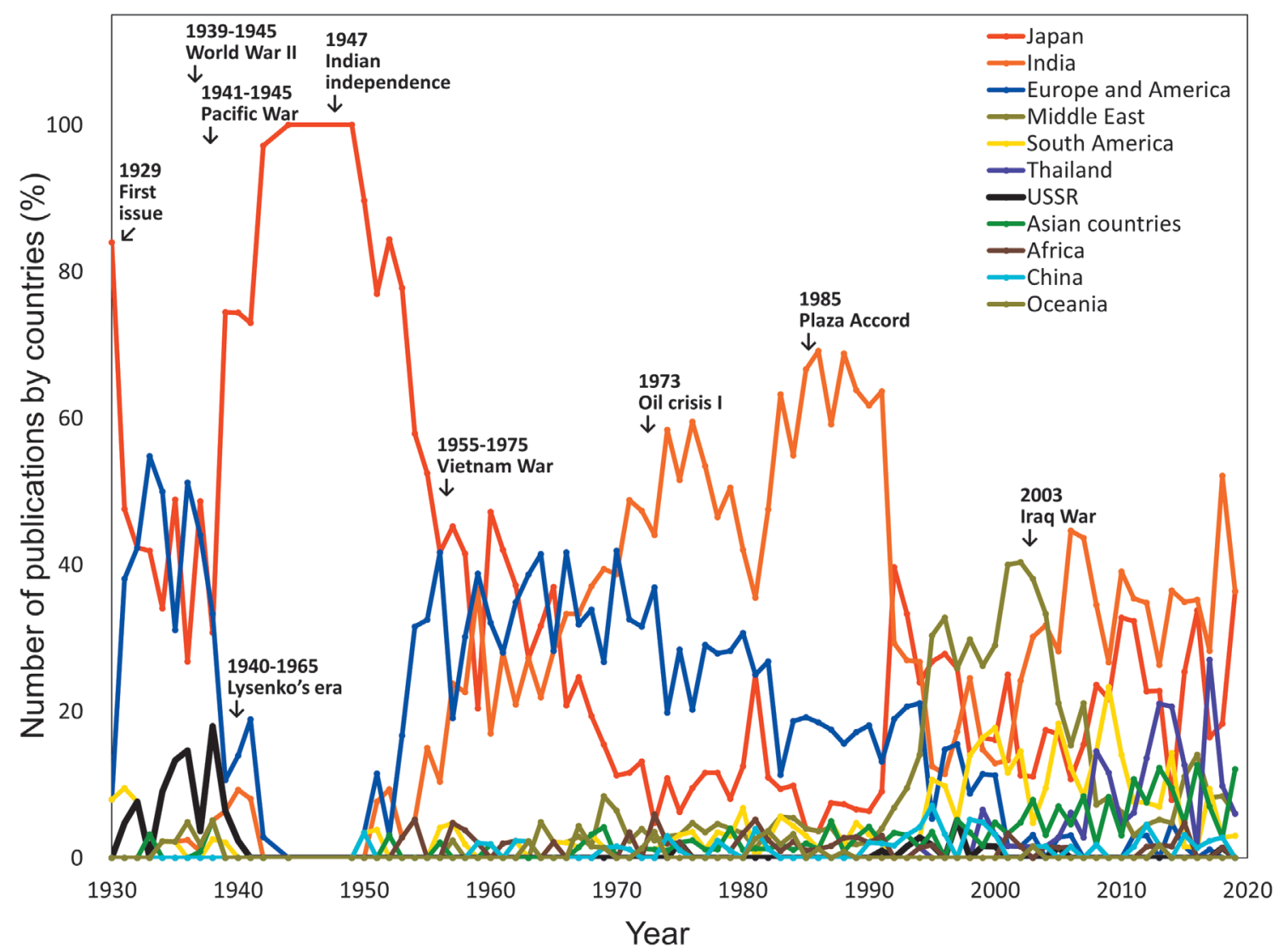

Fig. 1. Number of publications by country at the 90th anniversary of Cytologia; data are percentages.

of chromosomes of eight wheat species, among which he discovered polyploidy of $2 n=14(2 x), 28(4 x)$, and 42 (6x). These results were published in July 1918; in December of that year Sakamura left Japan to study overseas for 2 years (Sakamura 1918).

Hitoshi Kihara entered the graduate school of Hokkaido University in August 1918. He accepted Sakamura's offer to take over his materials and in 1918 started working on the $5 x$ hybrids growing in the field of Hokkaido University. In addition to the $F_{1}$ hybrids produced by Sakamura, Kihara himself performed crosses to produce two triploid $\mathrm{F}_{1}$ hybrids, $T$. dicoccum ( $4 x$ species) $\times T$. monococcum $(2 x)$, and $T$. aegilopoides $(2 x) \times T$. dicoccum $(4 x)$. He analysed the meiotic chromosome behaviour of these hybrids and the number of somatic chromosomes of their offspring, and thus determined their genome constitution; this work opened a new era of genomic analysis. When Kihara moved to Kyoto University in October 1920, he received from Hokkaido University all of the wheat species studied by Sakamura, as stated above, and extended his genomic analyses to encompass all species of the genera Triticum and Aegilops. The genomic analysis of the genus Triticum was completed in 1951 (Lilienfeld and Kihara 1934, Kihara 1951, Lilienfeld 1951), as well as that of the genus Aegilops by Kihara (1949), the latter complemented by a study of its four hexaploid species by Kihara and Tanaka (1970).
In 1973, Tsunewaki's group at Kyoto University started an investigation of differentiation of plasmon in the Triticum-Aegilops complex; plasmons of this complex were introduced into 12 wheat genotypes, including three of Flaksberger's stocks. This resulted in the generation of 552 alloplasmic lines; their phenotypes and restriction fragment patterns of organellar DNAs were compared. The maternal and paternal lineages of most species in this complex were determined based on the results of that plasmon analysis and Kihara's genomic analysis (Tsunewaki et al. 2019).

\section{The era of Flaksberger and Lysenko}

The following brief biography of Flaksberger was taken from Tsunewaki's review (Tsunewaki 2018). Upon graduating in 1907 from the Department of Physics and Mathematics, Imperial Yuriev University, Russia, Flaksberger was immediately appointed Vice Director of the Bureau of Applied Botany, Ministry of Agriculture, Russia, where he worked throughout his life on the agrobotanical study of wheat. He published four editions of "Wheat Taxonomy," in 1915, 1922, 1928, and 1939. He was arrested on June 28, 1941, about one year after the arrest of Nikolai Vavilov and, sadly, died on September 13, 1942, in Zlatoust Prison Hospital in the Ural District at the age of 62 years.

N. Vavilov was a prominent Russian and Soviet agronomist, botanist, and geneticist best known for 
identifying the centres of origin of cultivated plants. He devoted his life to the study and improvement of wheat, corn, and other cereal crops that sustain the global population. Vavilov visited Japan in 1929 and met Kihara, a wheat geneticist at Kyoto Imperial University, and delivered, in English, a lecture entitled "The Origin of Cultivated Plants." However, Vavilov's work was criticised by Trofim Lysenko, whose anti-Mendelian concepts of plant biology had won favour with the Soviet dictator, Joseph Stalin. As a result, Vavilov was arrested and in July 1941 was sentenced to death. Although his sentence was commuted to 20 years' imprisonment, Vavilov tragically died of starvation in prison in 1943.

Lysenko's theory assumed the heritability of acquired traits, denied Mendel's inheritance and the concept of genes, and deviated from Darwinian evolution but, with Stalin's support, gained power rapidly (Soyfer 2001). In 1936 he became a director of the Kiev Agricultural Institute and fought a fierce battle with orthodox geneticists, and in 1939 he became a member of the Soviet Academy of Sciences and won a decisive victory at the debate that year. From 1940 to 1965, Lysenko served as director of the Institute of Genetics of the Soviet Academy of Sciences, and the defeated orthodox geneticists were arrested, expelled, or forced to change their views. The farming methods advocated and practiced by Lysenko devastated Soviet agriculture, but this reality was hidden from the wider world. Cytologia published 34 articles from the Soviet Union from 1930 to 1940; however, after 1941, when the German-Soviet war began, no article from the Soviet Union appeared. The last article was from the Cytological Laboratory of the Institute of Plant Industry in Leningrad-Pushkin (Lewitsky 1940).

\section{Post-war trajectory and a new ichthyologic trend}

A series of wheat genome studies by Kihara and coworkers is one of the highlights of Cytologia. The decade in which Cytologia had been launched was passing; the Second World War began in September 1939, the German-Soviet War in June 1941, and the Pacific War in December 1941, which affected Cytologia greatly. Submissions from the West, but not the Soviet Union, reappeared after the end of the Second World War. In addition, submissions from India, which became independent in 1947, saved Cytologia from a crisis. However, in the 1990s, the Indian economy stagnated while those of other Asian countries increased. In fact, numerous articles have been submitted from three regions: North India (including Himalaya), Bangladesh downstream of the Ganges and Brahmaputra Rivers and around their delta, and Thailand (including Indochina and the northern Malay peninsula) (Kawano 2018).

In Thailand, including Indochina and the northern Malay peninsula, Alongklod Tanomtong and coworkers have recently focused on fish karyotype analysis and have published 15 reports in Cytologia over the last 2 years on the following fish species: Humpback cardinalfish, Fibramia lateralis (Kasiroek et al. 2017a); Banggai cardinalfish, Pterapogon kauderni (Kasiroek et al. 2017b); triangle butterflyfish, Chaetodon triangulum and yellow butterflyfish, $C$. andamanensis (Supiwong et al. 2017a); Indian vagabond butterflyfish, Chaetodon decussatus and Lined butterflyfish, C. lineolatus (Supiwong et al. 2017b); Nile tilapia, Oreochromis niloticus (Sriuttha et al. 2017); three-spot damselfish, Dascyllus trimaculatus (Getlekha et al. 2017); ocellated dragonet, Synchiropus ocellatus and picturesque dragonet, S. picturatus (Kasiroek et al. 2017c); crystal eye catfish, Hemibagrus wyckii (Supiwong et al. 2017d); Chevey's sheetfish, Micronema cheveyi (Pinthong et al. 2017); $F_{1}$ hybrid catfish: Mekong giant catfish, Pangasianodon gigas $\times$ striped catfish, $P$. hypophthalmus and spot pangasius, Pangasius larnaudii $\times$ Pangasianodon hypophthalmus (Sreeputhorn et al. 2017); whitecheek monocle bream, Scolopsis vosmeri (Supiwong et al. 2017c); snakehead fishes, Channa marulius and C. marulioides (Sarasan et al. 2018); Hihgfin barb fish, Cyclocheilichthys armatus (Chaiyasan et al. 2018); black lancer, Bagrichthys majusculus (Supiwong et al. 2018); and longfin carp, Labiobarbus leptocheilus (Saenjundaeng et al. 2018).

In response to these reports from Thailand, Cytologia recently published several analyses of fish karyotypes from the Middle East and South America. Ayata et al. (2018) reported the diploid chromosome number, karyotype, and chromosomal-banding properties (C-banding and Ag staining) in Cobitis phrygica and C. simplicispina from Turkey. At least 18 species of the genus Cobitis of the family Cobitidae are known in Turkey. The endemic species $C$. phrygica is distributed in the watersheds of the Acıgöl, Salda, and Sögüt Lakes in Turkey and C. simplicispina is distributed in the Sakarya and Kizilırmak basins and around Tuz Lake. The distribution of Cobitis in Turkey was revised recently because of complex problems regarding their systematics and phylogeny.

Chromosomal investigation is useful for solving systematic and taxonomic problems in fish. However, the difficulty in obtaining chromosomes from fishes, the small size and the large number of their chromosomes, and the lack of a standard method has hampered such investigations. Studies published in Cytologia typically aim to evalute chromosomal properties by conventional cytogenetic (Giemsa, Ag-NOR, and banding-C staining) and cytomolecular (fluorescence in situ hybridization using 5S, 18S rDNA, Rag1, Rex3, Rex6, and telomeric probes) markers in the following endemic loach species: Cichla kelberi and C. piquiti from Brazil (de Freitas Mourão et al. 2017); the Astyanax scabripinis population in the São Francisco River, Brazil (Klassmann and dos Santos 2017); and the Moenkhausia sanctaefilomenae population in the Upper Paraná River 
basin, Brazil (Fernandes and Alves 2017).

\section{Recent developments in cereal cytogenetic research}

Several reports on Poaceae have been published in Cytologia over the past 2 years (Gupta, et al. 2018, Khah and Verma 2017, Rani et al. 2017, Kaur and Gupta 2018, Özer et al. 2018, Shiogai et al. 2018). A useful review on the wheat genome was published by Tsunewaki in 2018, and the expression profiles of two long noncoding RNAs in salt-stressed barley roots were detailed by Karlik et al. (2018) in the same year.

Gupta and coworkers at Punjabi University and Khalsa College in 2017 reported male meiotic studies of 20 species belonging to 14 genera of the tribe Andropogoneae from the State of Haryana in northern India and its adjoining hills, and some parts of Rajasthan. Haryana encompasses an area of $44212 \mathrm{~km}^{2}$ and is bordered to the south by Rajasthan. The Shivaliks are also known as sub-Himalaya or 'the foothills' and typically range in altitude from 900-1500 m, while a few exceed $2000 \mathrm{~m}$. Few studies have assessed the cytological diversity of grasses in these hills. The tribe Andropogoneae is commonly known as Sorghum. One Andropogoneae species is grown for grain, and others for fodder, and are cultivated in warm climates worldwide or have become naturalised in pasture lands.

Khah and Verma (2017) reported a case of multiple translocation heterozygosity in an $\mathrm{M}_{1}$ population following gamma irradiation of pearl millet (Pennisetum glaucum L.). P. glaucum, a member of the grass family, is the most widely cultivated type of millet. It is an important cereal crop and is a good material for cytological analysis as it has comparatively few suitably sized chromosomes $(2 n=14)$, which facilitates their staining. Pearl millet is rich in essential compounds such as proteins, fibre, phosphorous, magnesium, and iron. Because of its composition, pearl millet has health benefits and is a staple food for many people worldwide, particularly in Africa. The generation of mutants of this important cereal crop using physical or chemical mutagens is important for genetic studies and plant breeding programs. Rani et al. (2017) performed pachytene analyses of 18 accessions of three genera of minor millet: Eleusine indica, Panicum antidotale, and Setaria italica.

The genus Setaria is economically important for grain and forage. The genus falls under the tribe Paniceae and the family Poaceae. Kaur and Gupta (2018) investigated the cytological features of eight species and 16 accessions. S. geniculata $(2 n=54), S$. homonyma $(2 n=18)$, and $S$. italica $(2 n=36)$ were the first reported euploid cytotypes, and the cytological studies of Setaria barbata $(2 n=54), S$. glauca $(2 n=54), S$. pumila $(2 n=54)$, and $S$. verticillata $(2 n=108)$ were the first from Rajasthan.

Perennial ryegrass (Lolium perenne), which is cultivated across large areas in the temperate regions of the world, was the first cultivated and widely used grassland plant. The natural flora of Turkey is rich in Lolium species. Özer et al. (2018) proposed that Turkish perennial ryegrass populations may be relevant to chromosomal variation in the karyotype relationships between cytotypes, which could facilitate the development of new cultivars.

Poaceae species use the $\mathrm{C}_{4}$ photosynthetic pathway, as do $46 \%$ of grasses; together, these account for $61 \%$ of $\mathrm{C}_{4}$ species. Such species include the food crops maize, sugar cane, millet, and sorghum. Maize (Zea mays) is a representative $\mathrm{C}_{4}$ plant, but its senescing leaves exhibit $\mathrm{C}_{3}$-like photosynthetic properties. Under the culture conditions of Shiogai et al. (2018), first leaves of maize finished maturation by day 9 after sowing and subsequently began to exhibit a considerable degree of $\mathrm{O}_{2}$ inhibition, a $\mathrm{C}_{3}$-like photosynthetic property. They proposed that preferential senescence in the mesophyll cells (MCs) may cause insufficient $\mathrm{CO}_{2}$ pumping into the bundle sheath cells (BSCs) and lead to $\mathrm{C}_{3}$-like photosynthetic properties in senescing maize leaves.

The two main types of commercial grain crops are cereals and legumes. Grains and cereals are synonymous with caryopses, the fruits of the grass family, Poaceae. In agronomy and commerce, seeds or fruits from other plant families are called grains if they resemble caryopses. Cereal grain crops are grown in greater quantities and provide more food energy worldwide than any other type of crop and are, therefore, staple crops. Edible grains from other plant families, such as buckwheat (Polygonaceae) (Gupta et al. 2018), quinoa (Amaranthaceae), chia (Lamiaceae), and sesame (Pedaliaceae) (Das et al. 2018) are referred to as pseudocereals. In addition to these plants, a large number of papers on legumes have been published in Cytologia, indicating the diversity of food available in India (Ghosh et al. 2017, Chaudhary and Kumar 2017, Gosavi et al. 2017, Kumar and Singh 2018), Egypt (Siddiqui et al. 2018), and Mexico (Tapia-Pastrana et al. 2018). The 90-year history of $C y$ tologia shows that karyotype analysis is an excellent tool for diversity research.

\section{Acknowledgements}

Cytologia is supported by a Grant from JSPS KAKENHI (15HP2012). I would like to thank Dr. Tsuyoshi Takeshita for useful comments and technical support. I would also like to express my gratitude to M. Okami and S. Hosokawa for collecting data.

\section{References}

Ayata, M. K., Unal, S. and Gaffaroğlu, M. 2018. Chromosomal analyses of Cobitis phrygica Battalgazi, 1944 and C. simplicispina Hanko, 1925 (Teleostei, Cobitidae). Cytologia 83: 295-299.

Chaiyasan, P., Supiwong, W., Saenjundaeng, P., Seetapan, K., Pinmongkhonkul, S. and Tanomtong, A. 2018. A report on classical cytogenetics of highfin barb fish, Cyclocheilichthys armatus 
(Cypriniformes, Cyprinidae). Cytologia 83: 149-154.

Chaudhary, N. and Kumar, G. 2017. Cytogenetical study of induced desynaptic variants in Phaseolus vulgaris L. Cytologia 82: 287-291.

Das, D., Datta, A. K., Kumbhakar, D. V., Ghosh, B. and Pramanik, A. 2018. Cytogenetical study of intervarietal hybrids of sesame (Sesamum indicum L., Pedaliaceae) raised by open pollination. Cytologia 83: 159-163.

de Freitas Mourão, A. A., Daniel, S. N., Hashimoto, D. T., Ferreira, D. C. and Porto-Foresti, F. 2017. Organization and distribution of repetitive DNA classes in the Cichla kelberi and Cichla piquiti genome. Cytologia 82: 193-197.

Fernandes, C. A. and Alves, D. S. 2017. Occurrence of multiple euchromatic B microchromosomes in Moenkhausia sanctaefilomenae (Pisces, Characidae) from the Upper Paraná River Basin, Brazil. Cytologia 82: 547-550.

Getlekha, N., Supiwong, W., Yeesin, P., Pengseng, P., Kasiroek, W. and Tanomtong, A. 2017. Chromosomal characteristics of the three-spot damselfish, Dascyllus trimaculatus (Perciformes, Pomacentridae) in Thailand. Cytologia 82: 51-57.

Ghosh, B., Datta, A. K., Pramanik, A., Kumbhakar, D. V., Das, D., Paul, R. and Biswas, J. 2017. Mutagenic effectivity of cadmium sulphide and copper oxide nanoparticles on some physiological and cytological attributes of Lathyrus sativus L. Cytologia $\mathbf{8 2}$ : 267-271.

Gosavi, K. V. C., Gholave, A. R. and Yadav, S. R. 2017. Karyomorphology of the genus Eleiotis (Fabaceae) from India. Cytologia 82: $543-545$.

Gupta, H., Gupta, R. C., Kuma, R. and Singhal, V. K. 2018. Spontaneous occurrence of structural heterozygosity in buckwheat' (Fagopyrum acutatum) from the Parvati Valley, Himachal Pradesh, India. Cytologia 83: 201-205.

Karlik, E., Marakli, S. and Gozukirmizi, N. 2018. Two lncRNA expression profiles in salt-stressed barley (Hordeum vulgare L.) roots. Cytologia 83: 37-43.

Kasiroek, W., Indananda, C., Luangoon, N., Pinthong, K., Supiwong, W. and Tanomtong, A. 2017a. First chromosome analysis of the humpback cardinalfish, Fibramia lateralis (Perciformes, Apogonidae). Cytologia 82: 9-15.

Kasiroek, W., Indananda, C., Pinthong, K., Supiwong, W., Pengseng, P. and Tanomtong, A. 2017b. NOR Polymorphism and chromosome analysis of banggai cardinalfish, Pterapogon kauderni (Perciformes, Apogonidae). Cytologia 82: 17-23.

Kasiroek, W., Luangoon, N., Supiwong, W., Tengjaroenkul, B., Pinthong, K. and Tanomtong, A. 2017c. First report of chromosome analysis of two dragonets (Perciformes, Callionymidae). Cytologia 82: 59-65.

Kaur, N. and Gupta, R. C. 2018. Male meiosis in some species of genus Setaria L. from different geographical regions of Rajasthan, India. Cytologia 83: 63-66.

Kawano, S. 2018. Karyotype and chromosome behavior analyses in three regions of the Indomalayan realm. Cytologia 83: 223-228.

Khah, M. A. and Verma, R. C. 2017. Cytological characterization of induced multiple translocation heterozygote in pearl millet (Pennisetum glaucum L.). Cytologia 82: 443-447.

Kihara, H. 1929. Conjugation of homologous chromosomes in the genus hybrids Triticum $\times$ Aegilops and species hybrids of Aegilops. Cytologia 1: 1-15.

Kihara, H. 1949. Genomanalyze bei Triticum und Aegilops. IX. Systematischer aufbau der gattung aegilops auf genomanalytischer groudlage. Cytologia 14: 135-144.

Kihara, H. 1951. Substitution of nucleus and its effects on genome manifestation. Cytologia 16: 177-193.

Kihara, H. and Tanaka, M. 1970. Addendum to the classification of the genus Aegilops by means of genome-analysis. Wheat Inform. Serv. 30: $1-2$.
Klassmann, J. P. and dos Santos, I. C. M. 2017. Karyotype diversity in Astyanax sacbripinnis (Pisces, Characiformes) from the São Francisco River Basin, Brazil. Cytologia 82: 199-203.

Kumar, G. and Singh, S. 2018. Nuclear polymorphism induced genomic instability in cluster bean [Cyamopsis tetragonoloba $(\mathrm{L}$. Taub.] (Fabaceae). Cytologia 83: 137-141.

Lewitsky, G. A. 1940. A cytological study of the progeny of X-rayed Crepis capillaris Wallr. Cytologia 11: 1-29.

Lilienfeld, F. A. 1951. H. Kihara: Genome-analysis in Triticum and Aegilops. X. Concluding review. Cytologia 16: 101-123.

Lilienfeld, F. and Kihara, H. 1934. Genome-analysis in Triticum and Aegilops. V. Triticum timopheevi Zhuk. Cytologia 6: 87-122.

Özer, İ., Tamkoç, A. and Uysal, T. 2018. Determination of chromosome structures of genotypes of perennial ryegrass (Lolium perenne L.) selected from natural vegetation of Turkey. Cytologia 83: 415-419.

Pinthong, K., Supiwong, W., Simporn, B., Chooseangjaew, S., Kakampuy, W. and Tanomtong, A. 2017. A first chromosomal and nucleolar organizer regions (NORs) analysis of Chevey's sheetfish, Micronema cheveyi (Siluriformes, Siluridae). Cytologia 82: 435-441.

Rani, M., Sujata and Srivastava, A. K. 2017. Pachytene analyses in some genera of minor millets. Cytologia 82: 521-526.

Saenjundaeng, P., Kaewmad, P., Supiwong, W., Pinthong, K., Pengseng, P. and Tanomtong, A. 2018. Karyotype and characteristics of nucleolar organizer regions in longfin carp, Labiobarbus leptocheilus (Cypriniformes, Cyprinidae). Cytologia 83: 265-269.

Sakamura, T. 1918. Kurze Mitteilung über die Chromosomenzahlen und die Verwandtchafts-verhältnisse der Triticum-Arten. Bot. Mag. 32: 150-153.

Sarasan, T., Jantarat, S., Supiwong, W., Yeesin, P., Srisamoot, N. and Tanomtong, A. 2018. Chromosomal analysis of two snakehead fishes, Channa marulius (Hamilton, 1822) and C. marulioides (Bleeker, 1851) (Perciformes: Channidae) in Thailand. Cytologia 83: $115-121$.

Shiogai, S., Tamotsu, S. and Sakai, A. 2018. C 3 -Like photosynthetic properties of senescing maize leaves are accompanied by preferential senescence of mesophyll cells. Cytologia 83: 387-391.

Siddiqui, S., Alamri, S., Al-Rumman, S. and Moustafa, M. 2018. Allelopathic and cytotoxic effects of medicinal plants on vegetable crop pea (Pisum sativum). Cytologia 83: 277-282.

Sreeputhorn, K., Mangumphan, K., Muanphet, B., Tanomtong, A., Supiwong, W. and Kaewmad, P. 2017. The first report on chromosome analysis of $\mathrm{F}_{1}$ hybrid catfish: Mekong giant catfish (Pangasianodon gigas) $\times$ striped catfish (Pangasianodon hypophthal$m u s$ ) and spot pangasius (Pangasius larnaudii) $\times$ Pangasianodon hypophthalmus (Siluriformes, Pangasiidae). Cytologia 82: 457463.

Sriuttha, M., Khammanichanh, A., Patawang, I., Tanomtong, A., Tengjaroenkul, B. and Neeratanaphan, L. 2017. Cytotoxic assessment of Nile tilapia (Oreochromis niloticus) from a domestic wastewater canal with heavy metal contamination. Cytologia 82: $41-50$.

Supiwong, W., Boonsuk, J., Jantarat, S., Suvarnaraksha, A., Pengseng, P. and Tanomtong, A. 2017a. The first chromosomal characteristics of nucleolar organizer regions and karyological analysis of two chaetodontid fishes (Perciformes, Chaetodontidae). Cytologia 82: 33-39.

Supiwong, W., Boonsuk, J., Jumrusthanasan, S., Pinthong, K., Suvarnaraksha, A. and Tanomtong, A. 2017b. First report of chromosome analysis of two chaetodontid fishes (Perciformes, Chaetodontidae). Cytologia 82: 25-31.

Supiwong, W., Phimphan, S., Kaewmad, P., Saenjundaeng, P., Jantarat, S. and Tanomtong, A. 2017c. First cytogenetic study of the whitecheek monocle bream, Scolopsis vosmeri (Perciformes, Nemipteridae) from Thailand. Cytologia 82: 481-484. 
Supiwong, W., Saenjundaeng, P., Maneechot, N., Chooseangjaew, S., Pinthong, K. and Tanomtong, A. 2017d. A discovery of nucleolar organizer regions (NORs) polymorphism and karyological analysis of crystal eye catfish, Hemibagrus wyckii (Siluriformes, Bagridae) in Thailand. Cytologia 82: 403-411.

Supiwong, W., Getlakha, N., Chaiphech, S., Pinthong, K., Phimphan, S. and Tanomtong, A. 2018. Nucleolar organizer regions polymorphism and karyological analysis of black lancer, Bagrichthys majusculus (Siluriformes, Bagridae) in Thailand. Cytologia 83: 193-199.

Soyfer, V. N. 2001. The consequences of political dictatorship for
Russian science. Nat. Rev. Genet. 2: 723-729.

Tapia-Pastrana, F., Gómez-Acevedo, S. and Mercado-Ruaro, P. 2018. Differences in karyotypes between two populations of Crotalaria incana from Mexico. Cytologia 83: 431-435.

Tsunewaki, K. 2018. Dawn of modern wheat genetics: The story of the wheat stocks that contributed to the early stage of wheat cytogenetics. Cytologia 83: 351-364.

Tsunewaki, K., Mori, N. and Takumi, S. 2019. Experimental evolutionary studies on the genetic autonomy of the cytoplasmic genome "plasmon" in the Triticum (wheat)-Aegilops complex. Proc. Natl. Acad. Sci. U.S.A. 116: 3082-3090. 